\title{
ДОВГОЛІТТЯ КОРІВ МОЛОЧНОЇ ХУДОБИ ЗАЛЕЖНО ВІД МЕТОДІВ РОЗВЕДЕННЯ
}

\author{
Хмельничий Сергій Леонтійович \\ кандидат сільськогосподарських наук, ст. викладач \\ Сумський національний аграрний університет \\ ORCID: 0000-0003-2352-3317 \\ E-mail: serhiokh@ukr.net
}

Мартинова Юлія Володимирівна студентка магістратури біолого-технологічного факультету Сумський національний аграрний університет

ORCID: 0000-0001-8456-7378

E-mail: yuliia12795@gmail.com

Микитюк Петро Петрович

студентка магістратури біолого-технологічного факультету

Сумський національний аграрний університет

ORCID: 0000-0001-7838-2422

E-mail: petromykytiuk93@gmail.com

Кривченко Тетяна Олегівна

студентка магістратури біолого-технологічного факультету

Сумський національний аграрний університет

ORCID: 0000-0001-7260-7037

E-mail: krivchenko.tanya@gmail.com

Мяделець Віталій Валерійович

студентка магістратури біолого-технологічного факультету

Сумський національний аграрний університет

ORCID: 0000-0001-9574-0252

E-mail: mozevu2603031996@gmail.com

Науменко Марина Вікторівна

студентка магістратури біолого-технологічного факультету

Сумський національний аграрний університет

ORCID: 0000-0003-2307-0127

E-mail: nechytailomaryna@gmail.com

Досліджено тривалість та ефективність довічної продуктивності корів української чорно-рябої молочної породи різної кровності за голштинською породою та чистопородних голштинів вітчизняної селекції заводського стада. У межах генотипів було сформовано чотири піддослідні групи помісних корів з урахуванням умовної кровності за голштинською породою: I група 3/4-кровні; II група - 7/8; III - 15/16; IV - 31/32. Встановлено, що кращими показниками продуктивного довголіття відзначалися чистопородні голштини вітчизняного походження порівняно з помісями, одержаними за поглинального схрещування з бугаями голштинської породи. Найдовшою тривалістю життя (2633 дні) та найбільшою кількістю лактацій за життя $(5,2)$ характеризувалися корови з умовною часткою спадковості голштинів 3/4. При порівнянні чистопородних голштинських корів з помісними тваринами I та II груп високодостовірна різниця на користь помісних корів за тривалістю життя становила відповідно 378 та 289 днів (P<0,001), а за тривалістю лактацій - на 1,3 та 0,9 штук $(P<0,001)$. Зростання спадковості голштинської породи не спричинило у помісних тварин відповідного зменшення довічного надою. Від групи чистопородних голштинських корів з часткою крові голштина 96,88\% було отримано найвищий довічний надій (30327 кг) з перевищенням груп корів решти генотипів на 1575-4615 кг молока з достовірною різницею у порівняннях з помісними генотипами I-III груп $(P<0,001)$. 3 високою достовірністю чистопородні голштини переважали відповідні помісні групи за довічним виходом молочного жиру, відповідно на 68,1-164,6 ке (P<0,001). Надій чистопородних голштинських корів на один день життя становив 13,4 кг з перевищенням корів інших груп помісних генотипів на 1,2-3,6 ке з високим ступенем достовірності (P<0,001). Встановлена додатна кореляція між часткою спадковості голштина та тривалістю життя, кількістю використаних лактаиій, довічним надоєм, молочним жиром та надоєм на один день життя. Рівень умовної кровності на вміст жиру в молоці не вплинув. Із нарощуванням спадковості голштинської породи кореляційна залежність ознак довголіття від спадковості голштина істотно зменшувалася.

Ключові слова: українська чорно-ряба молочна, голштинська, умовна кровність, довічна продуктивність.

DOI: https://doi.org/10.32845/bsnau.Ivst.2021.1.15 
Продуктивне довголіття молочної худоби є досить важливою селекційною та економічною комплексною ознакою, яка істотним чином детермінується генетичними чинниками. Розроблена корифеями української науки $[3,9]$ методика виведення нових спеціалізованої молочної худоби передбачала широке використання на заключному етапі консолідації створюваних порід помісних за поліпшуючою породою корів з умовною кровністю голштина у межах 62,5$75,0 \%$. Проте, в останні десятиліття, за відсутності власної селекції бугаїв-плідників, застосовується система розведення за методикою відкритої популяції 3 використанням голштинських плідників зарубіжного походження.

Тривала практика розведення молочної худоби у світі довела, що голштинська порода істотно прискорює темпи приросту молочної продуктивності корів. Досвід країн 3 високим розвитком молочного скотарства свідчить, що при голштинізації $€$ можливість збільшити середній надій на корову щорічно більше ніж на 100 кг [19], але, разом $з$ тим, існує зворотній бік даного процесу - із нарощуванням кровності за голштинською породою знижуються показники відтворної здатності, тривалості використання та довічної продуктивності тварин [8, 14, 15, 17, 22].

Оскільки подальше удосконалення корів українських молочних порід відбувається за використання плідників голштинської породи, актуальність питання щодо продуктивного довголіття наразі загострюється, оскільки, як свідчать вітчизняні дослідження, використання генофонду голштинської породи супроводжується підвищенням вимогливості їхнього висококровного потомства до умов годівлі та утримання i, як наслідок, до зниження показників господарськи корисних ознак, у тому числі й продуктивного довголіття [4, $5,7,23,26,27,28]$.

У зв'язку з цим наукові дослідження з вивчення проблеми впливу умовної кровності голштинської породи на ознаки молочної продуктивності корів українських молочних порід не втрачають актуальності. Так, при вивченні молочної продуктивності корів різних генотипів української чорнорябої молочної породи встановлено, що з наростанням у генотипі тварин спадковості голштинської породи у них підвищуються надої, однак значно знижується вміст жиру в молоці, що підтверджує антагоністичний характер цих ознак [13].

За дослідженнями впливу умовної частки крові за голштинською породою на формування молочної продуктивності корів української чорно-рябої молочної породи у стадах ПЗ "Маяк" (Черкаської обл.) та АФ "Владана" (Сумської обл.) встановлено, що кращими за величиною надою першої лактації виявились помісні тварини обох підконтрольних стад з найвищою часткою поліпшувальної крові, тоді як у низькокровних тварин надій був достовірно нижчий. Поглинальний ефект голштинами української чорно-рябої молочної породи в процесі селекції на нарощування надою не вплинув на зниження вмісту жиру в молоці [2].

Відомо про достовірний вплив спадковості поліпшувальної породи на молочну продуктивність корів української червоно-рябої молочної ТОВ "Мена-Авангард" Чернігівської області. Автором встановлено, що надій корів 3 кожним прилиттям крові поліпшувальної породи відповідно на 12,5\% у межах помісних груп зростав [21]. За дослідженнями корів української червоно-рябої молочної та голштинської порід стада ДП ДГ "Христинівське" з урахуванням умовної кровно- сті за поліпшувальною породою відмічено тенденцію до криволінійного підвищення надою первісток із зростанням умовної частки спадковості голштина [30].

Перспектива селекції створених українських молочних порід, за використання у цьому процесі тварин різних генотипів, потребує моніторингу з визначення залежності ознак довічної продуктивності від усіх можливих спадкових чинників, у тому числі й від частки умовної кровності поліпшувальної породи. Через це, метою даних досліджень постало вивчення тривалості продуктивного використання й довічної продуктивності корів української чорно-рябої молочної породи різної кровності за голштинською породою та чистопородних голштинів вітчизняної селекції.

Матеріали та методи досліджень. Експериментальною базою проведених досліджень служила селекційна інформація стада підприємства племінного заводу СВК АФ "Перше Травня" Сумського району Сумської області. Ретроспективну оцінку корів української чорно-рябої молочної породи за ознаками молочної продуктивності у межах генотипів за враховані лактації проводили за показниками бази даних автоматизованого обліку господарства. У межах генотипів було сфрормовано чотири піддослідні групи помісних корів з урахуванням умовної кровності за голштинською породою: І група 3/4-кровні; II група - 7/8; III - 15/16; IV 31/32. Остання група згідно Інструкції з бонітування великої рогатої худоби молочних і молочно-м'ясних порід належать до чистопородних тварин, які $€$ тваринами V-го покоління, що одержані при вбирному схрещуванні неспоріднених порід і мають виражений тип з віднесенням їх до поліпшуючої породи [18]. У зв'язку з цим останнім часом в процесі атестації племінних стад практикується зміна загальноприйнятої назви, як селекційного досягнення [1], на голштинську породу.

Показники довічної продуктивності для кожної тварини обчислювали за формулами запропонованими Ю.П. Полупаном [16]. Для оцінки тривалості та ефективності довічного використання по кожній досліджуваній корові фіксується інформація про дати народження (Дн) і дату $(Д в)$ вибуття зі стада. По кожній лактації ( $\boldsymbol{i}=\boldsymbol{n}$ включно з можливо незакінченою останньою) ураховується ії тривалість (Тлі), надій (Hi), вихід молочного жиру (МЖі) за усю лактацію, результати кожного отелення (число і стать приплоду або факт народження мерт-вого теляти). На підставі урахованих показників для кожної тварини за пропонованими формулами обчислюються наступні показники:

тривалість життя (днів) - Тж =Дв - Дн;

довічний надій (кг) - Hd = $\boldsymbol{\Sigma} \boldsymbol{H}$;

довічний вихід молочного жиру (кг) - МЖд = $\Sigma$ МЖі;

середній надій на 1 день життя (кг) - Ндж = Нд / Тж ;

У разі вибуття корови до закінчення (запуску) останньої лактації (вкорочена лактація менше 305 днів) число лактацій за життя (Лж) обчислюється за формулою - Лж = (n - 1) + Tлn/305

Біометричне опрацювання результатів досліджень проводили за формулами, наведеними Е. К. Меркурьевой [11] на ПК з використанням програмного забезпечення.

Результати досліджень. У племінному заводі «Перше травня» генотип тварин української чорно-рябої молочної породи великої рогатої худоби формувався з 1985 року шляхом схрещування маточного поголів'я чистопородної лебединської породи із плідниками голштинської та україн- 
ської чорно-рябої молочної порід. У процесі тривалої селекційно-племінної роботи, завдяки використанню генетичного потенціалу поліпшуючих порід, було суттєво покращено молочну продуктивність тварин, змінено тип будови тварин тіла в бік молочного [12]. Традиційно дане стадо було створене за відомою схемою відтворного схрещування [3, 24]. Використання на різних етапах схрещування помісних бугаїв за голштинською породою створило різноманітність генотипового складу маточного поголів'я тварин. Наразі це високопродуктивне стадо зі значною кількістю поголів'я з високою кровністю голштинської породи, отриманого від поглинального схрещування, у тому числі й $\mathrm{V}$-го покоління, які віднесені до чистопородної голштинської породи.

За даними держплемреєстру 2019 року [6] середній надій на корову по стаду на 01.01.2020 р. склав 6377 кг, з виходом молочного жиру 197 та білка 204 кг, від корівпервісток було надоєно 6287 кг із загальним виходом молочного жиру 234 та білка 197 кг. Дані продуктивності за першу лактацію підтверджують високі потенційні можливості стада.

Огляд вище зазначених літературних джерел свідчить, що 3 підвищенням частки спадковості голштинської породи у тварин створених українських молочних порід показники продуктивного довголіття знижуються. Н. П. Мазур зі співавторами [10] повідомляє, що кращими показниками продуктивного довголіття відзначалися чистопородні тварини вітчизняних порід порівняно з помісями, одержаними за поглинального схрещування 3 бугаями голштинської породи. Подібні результати отримані нашими дослідженнями. 3 поміж підконтрольного помісного поголів'я української чорно-рябої молочної породи племінного заводу СВК АФ "Перше Травня" найдовшою тривалістю життя та найбільшою кількістю лактацій за життя характеризувалися корови з умовною часткою спадковості голштинів 3/4 $(75,0 \%)$.

Аналіз підконтрольних груп помісних корів різних генотипів за показниками тривалості життя та кількості лактацій засвідчив, що ці ознаки зазнають закономірного впливу умовної частки спадковості голштинської породи. Даний висновок підтверджується порівняльним аналізом результа- тів досліджень, наведених у табл. 1, який показує, що із зростанням у помісних корів умовної частки кровності за поліпшувальною породою відповідно зменшувалися терміни їхнього використання.

У помісних корів бажаного генотипу 3 кровністю голштина 75,0\%, отриманих за поглинального схрещування, тривалість життя у стаді була найвищою і становила в середньому 2366 днів з використанням тварин упродовж 5,2 лактацій.

3 поступовим нарощуванням спадковості голштинської породи, за використання у варіанті підбору чистопородних бугаїв-плідників, тривалість життя корів та кількість використаних лактацій у наступних двох групах помісних тварин з кровністю 87,5 та 93,75\% аналогічно скорочувалась і склала у корів II та III групи відповідно 2544 дні та 4,8 лактації і 2366 днів та 4,2 лактацій. Різниця корів II та III груп у порівнянні I групою склала за тривалістю життя 89 (недостовірна) та 267 днів $(\mathrm{P}<0,01)$, а за кількістю використаних лактацій - 0,4 $(P<0,05)$ та 1,0 $(P<0,001)$ лактацію.

Група корів зі спадковістю голштинської породи 96,88\%, які уже згідно інструкції з бонітування відносяться до чистопородних тварин, відрізнялася від попереднього покоління $(93,75)$ подальшим істотним зниженням тривалості життя на 111 днів з недостовірною різницею та достовірним скороченням на 0,3 лактацій $(P<0,05)$.

При порівнянні чистопородних голштинських корів 3 помісними I та II груп високодостовірна різниця на користь помісних корів за тривалістю життя становила відповідно 378 та 289 днів $(P<0,001)$, а за тривалістю лактацій - на 1,3 та 0,9 штук $(P<0,001)$.

Економічна важливість показників з оцінки тварин за довічною продуктивністю з часом перейшла у ранг ознак з визначення племінної цінності, тому у деяких країнах Європи та Північної Америки тривалість господарського використання корів включена у систему селекції великої рогатої худоби, як селекційна ознака [29, 31, 32, 33], оскільки скорочення продуктивного довголіття корів негативно позначається на ефективності селекції через уповільнення темпів відтворення стада та інтенсивності добору в ньому.

Таблиця 1

Тривалість використання та довічна продуктивність корів різних генотипів української чорно-рябої молочної та голштинської порід

\begin{tabular}{|c|c|c|c|c|c|c|c|c|}
\hline \multirow{3}{*}{$\begin{array}{c}\text { Умовна кровність } \\
\text { за голштином }\end{array}$} & \multirow{3}{*}{ Група } & \multirow{3}{*}{$\mathrm{n}$} & \multirow{2}{*}{\multicolumn{2}{|c|}{ Тривалість }} & \multicolumn{3}{|c|}{ Довічна продуктивність } & \multirow{3}{*}{$\begin{array}{l}\text { Надій на оди } \\
\text { день життя, к }\end{array}$} \\
\hline & & & & & \multirow{2}{*}{ надій, кг } & \multirow{2}{*}{ \% жиру } & \multirow{2}{*}{ кг жиру } & \\
\hline & & & життя, дн. & лактацій, шт. & & & & \\
\hline $3 / 4(75,0 \%)$ & $\mathrm{I}$ & 38 & $2633 \pm 85,7$ & $5,2 \pm 0,15$ & $25712 \pm 756,4$ & $3,83 \pm 0,015$ & $984,8 \pm 43,7$ & $9,8 \pm 0,24$ \\
\hline $7 / 8(87,5 \%)$ & II & 64 & $2544 \pm 79,6$ & $4,8 \pm 0,12$ & $27812 \pm 758,6$ & $3,82 \pm 0,014$ & $1062,4 \pm 42,3$ & $10,9 \pm 0,26$ \\
\hline $15 / 16(93,75 \%)$ & III & 94 & $2366 \pm 57,4$ & $4,2 \pm 0,10$ & $28752 \pm 618,4$ & $3,81 \pm 0,011$ & $1081,3 \pm 27,2$ & $12,2 \pm 0,19$ \\
\hline $\begin{array}{c}31 / 32(96,88 \%) \\
\text { ч/п голштинська }\end{array}$ & IV & 135 & $2255 \pm 46,5$ & $3,9 \pm 0,08$ & $30327 \pm 475,3$ & $3,79 \pm 0,009$ & $1149,4 \pm 21,5$ & $13,4 \pm 0,15$ \\
\hline
\end{tabular}

Оцінюючи довічну продуктивність корів піддослідних генотипів за величиною надою можна зробити узагальнюючий висновок, який свідчить про існування прямолінійного зв'язку між умовною кровністю за поліпшуючою породою і надоєм за життя. Він полягає у тому, що зростання спадковості голштинської породи не спричинило у помісних тварин відповідного зменшення довічного надою. Так, від групи чистопородних голштинських корів з часткою крові голштина 96,88\% було отримано найвищий довічний надій (30327 кг) 3 перевищенням груп корів решти генотипів на 1575-4615 кг молока 3 достовірною різницею у порівняннях 3 помісними генотипами І-ІІІ груп $(P<0,001) .3$ високою достовірністю чистопородні голштини переважали відповідні помісні групи за довічним виходом молочного жиру, відповідно на 68,1164,6 кг $(\mathrm{P}<0,001)$.

Жирномолочність помісних корів різних генотипів при зміненні часток спадковості вихідних лебединської та голштинської порід не зазнала відчутного впливу поліпшуючої породи. Між вмістом жиру в молоці корів зі спадковістю голштина $75,0 \%$ та чистопородними тваринами $(96,88 \%)$ встановлена незначна але достовірна різниця - 0,04\% $(\mathrm{P}<0,05)$. 
У якості певного інтегрованого показника, який найкращим чином характеризує генетичний потенціал тварин за молочною продуктивністю, незалежно від тривалості використання та довічної продуктивності, $€$ надій корів на один день їхнього життя. За результатами наших досліджень надій чистопородних голштинських корів на один день життя становив 13,4 кг з перевищенням корів інших груп помісних генотипів на 1,2-3,6 кг з високим ступенем достовірності $(\mathrm{P}<0,001)$.

Узагальнення одержаних результатів досліджень спонукає до висновку, що у перспективі, з подальшим нарощуванням спадковості голштинської породи у наявного помісного поголів'я корів та за удосконалення уже вітчизняних голштинів в системі відкритої популяції, селекційний процес буде супроводжуватись зниженням тривалості використання корів, не втрачаючи рівня показників довічної молочної продуктивності.

У даному випадку $є$ слушною рекомендація авторів [40], що за відсутності бугаїв-плідників вітчизняної селекції, перспектива подальшого використання генофонду голштинської породи зарубіжної селекції потребує створення у господарствах таких умов, які б сприяли максимальній реалізації генетичного потенціалу висококровних генотипів, що у свою чергу, якщо не зупинить скорочення тривалості проду- ктивного використання корів, то принаймні дещо загальмує цей процес.

Оскільки організм тварини є єдиною самоуправляючою системою, що склалася у процесі еволюції, де окремі частини організму, органи, тканини, ознаки знаходяться у взаємному зв'язку один з одним, вивчення зв'язків між господарськи корисними ознаками має велике значення для селекційно-племінної роботи [20]. Задля ефективності добору за ознаками з низькою успадковуваністю облік ознак, що корелюють, має вирішальне значення. При цьому включення до селекції таких співвідносних ознак, успадковуваність яких дуже низька, - єдино можливий спосіб для досягнення успіху селекції.

Задля визначення наскільки показники довголіття корів залежать від умовної кровності голштинської породи з мінливістю у динаміці її нарощування, нами були вирахувані коефріцієнти кореляцій між цими ознаками, табл. 2.

Отримані результати кореляційного аналізу свідчать про достовірну залежність тривалості життя, кількості використаних лактацій, довічного надою, молочного жиру та надою на один день життя. Рівень умовної кровності на вміст жиру в молоці не впливає. Із нарощуванням спадковості голштинської породи кореляційна залежність ознак довголіття від спадковості голштина істотно зменшується.

Таблиця 2

\section{Коефіцієнти кореляції між часткою спадковості голштинської}

породи та показниками продуктивного довголіття корів, $\mathrm{r} \pm \mathrm{m}_{\mathrm{r}}$

\begin{tabular}{|l|c|c|c|}
\hline \multicolumn{1}{|c|}{ Корельована ознака } & \multicolumn{2}{|c|}{ Умовна кровність за голштинською породою, \% } \\
\cline { 2 - 4 } & $\begin{array}{c}75,0 \text { та } 87,5 \\
(\mathrm{n}=102)\end{array}$ & $\begin{array}{c}93,75 \\
(\mathrm{n}=94)\end{array}$ & $\begin{array}{c}96,88 \\
(\mathrm{n}=135)\end{array}$ \\
\hline Тривалість життя, днів & $0,188 \pm 0,033^{3}$ & $0,132 \pm 0,046^{2}$ & $0,095 \pm 0,039^{1}$ \\
\hline Лактацій за життя & $0,166 \pm 0,032^{3}$ & $0,112 \pm 0,048^{1}$ & $0,074 \pm 0,036^{1}$ \\
\hline Довічна продуктивність: & $0,235 \pm 0,035^{3}$ & $0,144 \pm 0,051^{2}$ & $0,102 \pm 0,038^{2}$ \\
\hline надій, кг & $-0,077 \pm 0,039^{1}$ & $-0,033 \pm 0,049$ & $-0,021 \pm 0,039$ \\
\hline вміст жиру в молоці, \% & $0,251 \pm 0,034^{3}$ & $0,127 \pm 0,054^{1}$ & $0,088 \pm 0,037^{1}$ \\
\hline кількість молочного жиру, кг & $0,129 \pm 0,036^{3}$ & $0,108 \pm 0,046^{1}$ & $0,079 \pm 0,035^{1}$ \\
\hline Надій на 1 день життя, кг & & \\
\hline Пр и м іт к а: ${ }^{1}-P<0,05 ;^{2}-P<0,01 ;{ }^{3}-P<0,001$.
\end{tabular}

Висновки. Встановлено, що кращими за показниками продуктивного довголіття відзначалися чистопородні голштини вітчизняного походження порівняно з помісями, одержаними за поглинального схрещування з бугаями поліпшувальної породи.
Із нарощуванням спадковості голштинської породи довічні надій та вихід молочного жиру корів зростали при незмінному вмісту жиру, проте тривалість життя та кількість використаних лактацій при цьому знижувались.

\section{Список використаної літератури:}

1. Буркат В. П., Костенко О. І., Холкін М. М. Селекційні досягнення у тваринництві. К. : Аграрна наука. 2000. 34 с.

2. Вечорка В. В., Хмельничий Л. М. Генетичні чинники впливу на продуктивність корів української чорно-рябої молочної породи. Розведення і генетика тварин. 2019. Вип. 57, С. 22-28.

3. Генетика, селекция и биотехнология в скотоводстве. Зубец М. В., Буркат В. П., Мельник Ю. Ф. [и др.]; под ред. М. В. Зубца, В. П. Бурката. К.: "БМТ", 1997. 722 с.

4. Гончаренко І. В. Тривалість господарського використання молочних корів як ознака селекції. Вісник аграрної науки. 2004. №6, С. 33-36.

5. Даниленко В. П., Рудик І. А. До питання ефрективності використання молочних порід у господарстві. Розведення і генетика тварин. К. 2012. Вип. 46, С. 63-66.

6. Державний реєстр суб'єктів племінної справи у тваринництві за 2019 рік. Романова О. В., Прийма С. В., Полупан Ю. П., Басовський Д. М.; загальна редакція Прийми С. В. Київ, 2020. Том II. 199 с. [Електронний ресурс] - Режим доступу: http://animalbreedingcenter.org.ua/images/files/deriplemreestr/deriplemreestr_tom2_2019.pdf (дата звернення 02.03.2021).

7. Кальчук Л. А., Пелехатий М. С. Зв'язок молочної продуктивності з показниками відтворної здатності та господарського використання у корів чорно-рябої породи. Науково-технічний бюлетень. Харків. 2001. №80, С. 64-67.

8. Клопенко Н. І., Ставецька Р. В. Генетична детермінація господарського використання корів молочного напряму продуктивності за вбирного схрещування. Технологія виробництва і переробки продукції тваринництва: 3б. наук. праць Біло- 
церк. нац. аграр. ун-т. Біла Церква, 2015. Вип. №1, С. 23-28.

9. Крупномасштабная селекция в животноводстве. Н. 3. Басовский, В. П. Буркат, В. И. Власов, В. П. Коваленко. К. : Асоціація "Україна", 1994. 360 с.

10. Мазур Н. П., Федорович Є. І., Федорович В. В. Продуктивне довголіття молочної худоби за різних методів розведення. Розведення і генетика тварин. К., 2018. Вип. 55. С. 102-112.

11. Меркурьева Е. К. Генетические основы селекции в скотоводстве. М.: Колос, 1977. 240 с.

12. Обливанцов В.В.Ефективність розведення сумського внутріпородного типу української чорно-рябої молочної породи великої рогатої худоби. Вісник Сумського національного аграрного університету. Серія : Тваринництво. 2014. Вип. 2(2). C. 58-63.

13. Пендюк А. Р., Федорович В. В., Мазур Н. П. Фенотиповий прояв ознак молочної продуктивності у корів різних генотипів української чорно-рябої молочної породи. Розведення і генетика тварин. 2019. Вип. 58, С. 33-40.

14. Полупан Ю. П. Ефективність довічного використання червоної молочної худоби. Розведення і генетика тварин. К.: Аграрна наука. 2000. Вип. 33. С. 97-105.

15. Полупан Ю. П. Ефективність довічного використання корів різних країн селекції. Вісник Сумського національного аграрного університету. Серія» Тваринництво». 2014. Вип. 2/2 (25), С. 14-20.

16. Полупан Ю. П. Методика оцінки селекційної ефективності довічного використання корів молочних порід. Методологія наукових досліджень з питань селекції, генетики та біотехнології у тваринництві. Матеріали науково-теоретичної конференції, присвяченої пам'яті академіка УААН Валерія Петровича Бурката (Чубинське, 25 лютого 2010 року). К. : Аграрна наука, 2010. С. 93-95.

17. Полупан Ю. П., Коваль Т. П. Ранний отбор коров по эфффективности пожизненного использования. Зоотехния. 2011. № 6, С. 4-5.

18. Про затвердження Інструкції з бонітування великої рогатої худоби молочних і молочно-м'ясних порід, Інструкції з ведення племінного обліку в молочному і молочно-м'ясному скотарстві та зразків форм племінного обліку в молочному і молочно-м'ясному скотарстві. [Електронний ресурс] - Режим доступу: https://zakon.rada.gov.ua/laws/show/z0095-04\#Text (дата звернення 02.03.2021).

19. Прохоренко П. Н. Методы повышения генетического потенциала продуктивности и его реализация в молочном скотоводстве. Вестник Орловского государственного Аграрного университета. 2008. Т.11. №2. С. 11-13.

20. Сакса Е. И., Борсукова О. Е. Эффективность инбридинга при выведении коров в высокопродуктивном стаде. Зоотехния. 2010. № 2, С. 2-4.

21 Салогуб А. М. Вплив генотипових та паратипових чинників на ознаки молочної продуктивності корів української червоно-рябої молочної породи. Розведення і генетика тварин. 2019. Вип. 57, С. 126-135.

22 Стрекозов Н. И., Сивкин Н. В Продуктивное долголетие коров при голштинизации чёрно-пёстрого скота. Генетика и разведение животных. 2014. № 2, С. 11-16.

23. Ференц Л. В., Федорович Е. И., Федорович В. В., Сирацкий И. С. [и др.] Хозяйственно-биологические особенности коров украинской черно-пестрой молочной породы разных генотипов в условиях Прикарпаття. Тезисы докладов Межд. научно-практ. конф. посвященной 60-летию зоотехн. науки Беларуси (15-16 октября 2009 г.) «Стратегия развития зоотехнической науки». Жодино. 2009. С. 162-163.

24. Формування внутріпородних типів молочної худоби. Буркат В. П., Єфіменко М.Я., Хаврук О. Ф., Близниченко В. Б. - К. : Урожай, 1992. 200 с.

25. Хмельничий Л. М., Бардаш Д. О. Показники довголіття корів української червоно-рябої молочної породи залежно від частки спадковості голштинської породи. Вісник Сумського НАУ. Серія «Тваринництво». 2019. Вип. 4(39). C.13-19. DOI: https://doi.org/10.32845/bsnau.lvst.2019.4.2

26. Хмельничий Л. М., Вечёрка В. В. Пожизненная продуктивность и длительность использования коров украинской красно-пестрой молочной породы разных генотипов. Пути продления продуктивной жизни молочных коров на основе оптимизации разведения, технологий содержания и кормления животных [текст]: материалы междунар. науч.- практ. конф., (2829 мая, пос. Дубровицы) / ВИЖ им. Л.К. Эрнста, 2015. С. 159-162.

27. Хмельничий Л. М., Вечорка В.В.Ефективність внутрішньолінійного розведення та поєднуваності ліній в селекції голштинської худоби. Вісник Сумського НАУ. Серія “Тваринництво”. 2010. Вип. 12 (18), С. 149-153.

28. Хмельничий Л. М., Салогуб А. М. Ефективність поєднання генеалогічних формувань в селекції молочної худоби. Збірник наукових праць Подільського держ. аграрно-технічного університету. Серія "Технологія виробництва і переробки продукції тваринництва". Кам'янець-Подільський. 2012. Вип. 20, С. 285-287.

29. Madgwick P. A., Gaddard M. E. Genetics and phenotypics parameters of longer vity in Australian dairy cattle. Dairu Sc. 1989. v. 72, № 10, P. 2624-2632.

30. Polupan Yu. P., Melnik Yu. F., Biriukova O. D. Influence of genetic factors on the productivity of соws. Розведення і генетика тварин. 2019. Вип. 58. С. 41-51.

31. Relationships of curly performance traits to lifetime profitability in Holstein cows. Kulak K. K., Dekkers I. C. M., McAllister A. J. [et al.]. Can. J. Anim. Sci. 1977. 77, P. 617-624.

32. The influence of additive and nonadditive gene action on lifetime jillds and profitability of dairy cattle. McAallister A. J., Lee A. J., Batra B. [et al.]. J. Dairy Sci. 1994. 77. № 8, P. 2400-2414.

33. Zarnseki A., Jamrozik J., Mroziec S. Wplejnej laktacji, wieku i sezonu ocielenia na uzytkowosc mleczna krow w obredie stad. Rock. nauk rol. B. 1991. № 3, P. 251-268. 


\section{References:}

1. Burkat V.P., Kostenko, O.I., and Holkin, M.M., 2000. Selektsiini dosiahnennia u tvarynnytstvi [Breeding achievements in animal husbandry]. K.: Agrarian Science, 34.

2. Vechorka, V.V., and Khmelnychyi, L.M., 2019. Henetychni chynnyky vplyvu na produktyvnist koriv ukrainskoi chorno-riaboi molochnoi porody [Genetic factors influence the productivity of cows Ukrainian Black-and-White dairy cattle]. Rozvedennia $i$ henetyka tvaryn, issue 57 , pp. 22-28.

3. Zubets, M. V., Burkat, V. P., Mel'nik, Yu. F. [et al]. ed. 2007. Zubtsa, M. V. and Burkata, V. P., Genetika, selektsiya i biotekhnologiya v skotovodstve [Genetics, Breeding and Biotechnology in cattle breeding]. Kiev: „БMT”.

4. Honcharenko, I.V., 2004. Tryvalist hospodars'koho vykorystannya molochnykh koriv yak oznaka selektsiyi [Duration of economic use of dairy cows as a sign of selection]. Visnyk ahrarnoyi nauky, issue 6, pp. 33-36.

5. Danylenko, V.P., and Rudyk, I.A., 2012. Do pytannya efektyvnosti vykorystannya molochnykh porid u hospodarstvi [To the question of efficiency use of dairy breeds in the husbandry]. Rozvedennya i henetyka tvaryn, issue 46, pp. 63-66.

6. Romanova, O.V., Priyma, S.V., Polupan, Yu. P.,and Basovsky, D.M., 2020. State Register of Breeding Entities in Animal Husbandry for 2019 [Derzhavnyi reiestr sub'iektiv pleminnoi spravy u tvarynnytstvi za 2019 rik]. In: S.V. Pryimy, ed. Vol. II., pp. 199. doi: http://animalbreedingcenter.org.ua/images/files/deriplemreestr/deriplemreestr tom2_2019.pdf

(access date 02.03.2021).

7. Kalchuk, L.A., and Pelekhatyi, M.S., 2001. Zviazok molochnoi produktyvnosti z pokaznykamy vidtvornoi zdatnosti ta hospodarskoho vykorystannia u koriv chorno-riaboi porody [Relationship of dairy productivity with reproductive performance and economic use in Black-and-White breed]. Naukovo-tekhnichnyi biuleten. Kharkiv, issue 80, pp. 64-67.

8. Klopenko N.I., and Stavetska, R.V., 2015. Henetychna determinatsiia hospodarskoho vykorystannia koriv molochnoho napriamu produktyvnosti za vbyrnoho skhreshchuvannia [Genetic determination of economic use cows of the dairy direction productivity for absorbing crossing]. Tekhnolohiia vyrobnytstva i pererobky produktsii tvarynnytstva: Zb. nauk. prats Bilotserk. nats. ahrar. un-t. Bila Tserkva, issue 1, pp. 23-28.

9. Basovskiy, N.Z., Burkat, V.P., Vlasov, V.I., and Kovalenko, V.P., 1994. Krupnomasshtabnaya selektsiya v zhivotnovodstve [Large-scale breeding in animal husbandry]. K. : Asotsiatsiya "Ukraïne".

10. Mazur, N. P., Fedorovych, Ye. I. and Fedorovych, V. V., 2018. Produktyvne dovholittia molochnoi khudoby za riznykh metodiv rozvedennia [Productive longevity of dairy cattle by different breeding methods]. Rozvedennia $i$ henetyka tvaryn, issue 55 , pp. 102-112.

11. Merkur'eva, E.K., 1977. Geneticheskie osnovy selektsii v skotovodstve [Genetic principles of selective breeding in cattle breeding]. Moskva: Kolos.

12. Oblyvantsov, V.V., 2014. Efektyvnist rozvedennia sumskoho vnutriporodnoho typu ukrainskoi chorno-riaboi molochnoi porody velykoi rohatoi khudoby [Efficiency of breeding Sumy intrabreed type of Ukrainian Black-and-White dairy breed of cattle]. Visnyk Sumskoho natsionalnoho ahrarnoho universytetu. Seriia : Tvarynnytstvo, issue 2(2), pp. 58-63.

13. Pendiuk, A.R., Fedorovych, V.V., and Mazur, N.P., 2019. Fenotypovyi proiav oznak molochnoi produktyvnosti u koriv riznykh henotypiv ukrainskoi chorno-riaboi molochnoi porody [Phenotypic expression of traits milk production in cows of different genotypes Ukrainian Black-and-White dairy cattle]. Rozvedennia i henetyka tvaryn, issue 58, pp. 33-40.

14. Polupan, Yu. P., 2000. Efektyvnist dovichnoho vykorystannia chervonoi molochnoi khudoby [Efficiency of lifetime use of Red dairy cattle]. Rozvedennia i henetyka tvaryn, issue 33, pp. 97-105.

15. Polupan, Yu. P., 2014. Efektyvnist dovichnoho vykorystannia koriv riznykh krain selektsii [Effectiveness of cows lifetime use in different countries of selection]. Visnyk Sumskoho natsionalnoho ahrarnoho universytetu. Seriia : Tvarynnytstvo, issue $2 / 2$ (25), pp. 14-20.

16. Polupan, Yu. P., 2010. Metodyka otsinky selektsiinoi efektyvnosti dovichnoho vykorystannia koriv molochnykh porid [Method of assessing the breeding efficiency of lifetime use cows of dairy breed]. In: Chubynske dedicated to the memory of UAAS Academician Valery Petrovich Burkat, Methodology of scientific research on breeding, genetics and biotechnology in animal husbandry, Proceedings of the International Conference, Chubynske, February 25, 2010. K.: Agrarna nauka, pp. 93-95.

17. Polupan, Yu.P., and Koval', T.P., 2011. Ranniy otbor korov po effektivnosti pozhiznennogo ispol'zovaniya [Early selection of cows on the effectiveness of lifetime use]. Zootekhniya, issue 6, pp. 4-5.

18. Pro zatverdzhennia Instruktsii z bonituvannia velykoi rohatoi khudoby molochnykh i molochno-miasnykh porid, Instruktsii z vedennia pleminnoho obliku v molochnomu i molochno-miasnomu skotarstvi ta zrazkiv form pleminnoho obliku v molochnomu i molochno-miasnomu skotarstvi. doi: https://zakon.rada.gov.ua/laws/show/z0095-04\# Text (data zvernennia 02.03.2021).

19. Prokhorenko, P.N. 2008. Metody povysheniya geneticheskogo potentsiala produktivnosti i ego realizatsiya v molochnom skotovodstve [Methods to improve the genetic potential of productivity and its implementation in dairy farming]. Vestnik Orlovskogo gosudarstvennogo Agrarnogo universiteta, issue 11(2), pp. 11-13.

20. Saksa, E.I., and Borsukova, O.E., 2010. Effektivnost inbridinga pri vyvedenii korov v vysokoproduktivnom stade [Efficiency of inbreeding during the breeding cows in a highly productive herd]. Zootekhniya, issue 2, pp. 2-4.

21. Salohub, A.M., 2019. Vplyv henotypovykh ta paratypovykh chynnykiv na oznaky molochnoi produktyvnosti koriv ukrainskoi chervono-riaboi molochnoi porody [Influence of genotypic and paratypical factors on dairy productivity trairs of cows of Ukrainian Red-and-White dairy breed]. Rozvedennia i henetyka tvaryn, issue 57, pp. 126-135.

22. Strekozov, N.I., and Sivkin, N.V., 2014. Produktivnoe dolgoletie korov pri golshtinizatsii cherno-pestrogo skota [Productive longevity of cows at the holsteinization Black-and-White cattle]. Genetika i razvedenie zhivotnykh, no. 2, pp. 11-16.

23. Ferents, L.V., Fedorovich, E.I., Fedorovich, V.V., and Siratskiy, I.S., 2009. Khozyaystvenno-biologicheskie osobennosti 
korov ukrainskoy cherno-pestroy molochnoy porody raznykh genotipov v usloviyakh Prikarpattya [Economic and biological features of cows of Ukrainian Black-and-White dairy breed of different genotypes in the conditions of Carpathians]. Tezisy dokladov Mezhd. nauchno-prakt. konf. posvyashchennoy 60-letiyu zootekhn. nauki Belarusi (15-16 oktyabrya 2009 g.) «Strategiya razvitiya zootekhnicheskoy nauki». Zhodino. pp. 162-163.

24. Burkat, V.P., Yefimenko, M.Ya., Khavruk, O.F., and Blyznychenko, V.B,. 1992. Formuvannya vnutriporodnykh typiv molochnoyi khudoby [The formation of intrabreed types of dairy cattle]. K. : Urozhay.

25. Khmelnychyi, L. M. and Bardash, D. O., 2019. Indicators longevity of cows Ukrainian Red-and-White dairy breed depending on the share of inheritance of Holstein breed [Pokaznyky dovholittia koriv ukrainskoi chervono-riaboi molochnoi porody zalezhno vid chastky spadkovosti holshtynskoi porody]. Visnyk Sumskoho natsionalnoho ahrarnoho universytetu. Seriia "Tvarynnytstvo", issue 4(39), pp. 13-19. doi: https://doi.org/10.32845/bsnau.Ivst.2019.4.2.

26. Khmelnychyi, L.M. and Vechorka, V.V., 2015. Pozhiznennaya produktivnost' i dlitel'nost' ispol'zovaniya korov ukrainskoy krasno-pestroy molochnoy porody raznykh genotipov [Lifetime productivity and duration of use cows Ukrainian Red-and-White dairy breed of different genotypes]. In: All-Russian Institute of Animal Husbandry named after L. K. Ernst, Ways to extend the productive life of dairy cows based on the optimization of breeding, keeping and feeding technologies, Proceedings of the International conference, Dubrovitsy, May 28-29, pp. 159-162.

27. Khmelnychyi, L.M., and Vechorka, V.V., 2010. Efektyvnist vnutrishnoliniinoho rozvedennia ta poiednuvanosti linii v selektsii holshtynskoi khudoby[Efficiency of intra-linear breeding and combining lines in Holstein cattle selection]. Visnyk Sumskoho NAU. Seriia "Tvarynnytstvo", issue 12(18), pp. 149-153.

28. Khmelnychyi, L.M., and Salohub, A.M., 2012. Efektyvnist poiednannia henealohichnykh formuvan v selektsii molochnoi khudoby [The effectiveness of the combination of genealogical groups in breeding dairy cattle]. Zbirnyk naukovykh prats Podilskoho derzh. ahrarnotekhnichnoho universytetu. Seriia "Tekhnolohiia vyrobnytstva i pererobky produktsii tvarynnytstva", issue 20, pp. 285-287.

29. Madgwick P. A., Gaddard M. E. Genetics and phenotypics parameters of longervity in Australian dairy cattle. Dairy Sc. 1989. v. 72, № 10, P. 2624-2632.

30. Polupan Yu. P., Melnik Yu. F., Biriukova O. D. Influence of genetic factors on the productivity of cows. Animal Breeding and Genetics. 2019. № 58, P. 41-51.

31. Relationships of curly performance traits to lifetime profitability in Holstein cows. Kulak K. K., Dekkers I. C. M., McAllister A. J. [et al.]. Can. J. Anim. Sci. 1977. № 77, P. 617-624.

32. The influence of additive and nonadditive gene action on lifetime jillds and profitability of dairy cattle. McAallister A. J., Lee A. J., Batra B. [et al.]. J. Dairy Sci. 1994. № 8, P. 2400-2414.

33. Zarnseki A., Jamrozik J., Mroziec S. Wplejnej laktacji, wieku i sezonu ocielenia na uzytkowosc mleczna krow w obredie stad. Rock. nauk rol. B. 1991. № 3, P. 251-268.

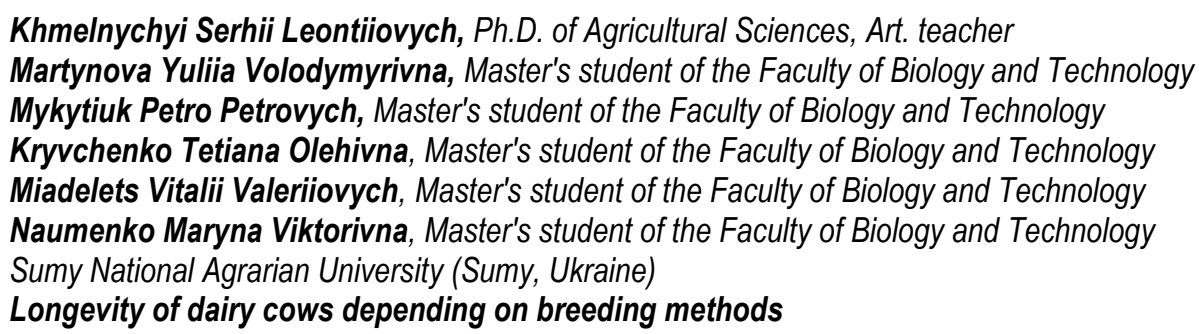

The duration and efficiency of lifelong productivity of cows of Ukrainian Black-and-White dairy breed of different blood by Holstein breed and purebred Holsteins of domestic selection of stud herd were studied. Within the genotypes, four experimental groups of crossbreed cows were formed, taking into account the conditional blood by Holstein breed: I group 3/4-blood; II group 7/8; III - 15/16; IV - 31/32. It was found that the best indicators of productive longevity were determined purebred Holsteins of domestic origin compared to crossbreds obtained by absorbing crosses with sires of Holstein breed. The longest lifetime (2633 days) and the largest number of lactations during life (5.2) were characterized by cows with a conditional share of Holstein heredity 3/4. When comparing purebred Holstein cows with domestic animals of groups I and II, the highly reliable difference in favor of hybrid cows in terms of lifetime was 378 and 289 days, respectively $(P<0.001)$, and in terms of lactation - by 1.3 and 0.9 pieces $(P<0.001)$. The growth of Holstein breed heredity did not lead to appropriate reduction of lifetime milk yield in the crossbreed animals. From the group of purebred Holstein cows with a share of Holstein blood $96.88 \%$ was obtained the highest lifetime yield (30327 kg) with the excess of cows group's of other genotypes by $1575-4615 \mathrm{~kg}$ of milk with a reliable difference compared to hybrid genotypes of groups I-III $(P<0.001)$. With high reliability, purebred Holsteins were dominated by the corresponding crossbreed groups in the lifetime yield of milk fat, respectively, by $68.1-164.6 \mathrm{~kg}(P<0.001)$. The milk yield of purebred Holstein cows for one day of life amounted $13.4 \mathrm{~kg}$ with the superiority of other cows group's of hybrid genotypes by 1.2-3.6 kg with a high degree of reliability $(P$ $<0.001)$. A positive correlation has been determined between the share of Holstein heredity and lifespan, the number of used lactations, lifelong milk yield, milk fat and milk yield per day of life. The level of conditional blood share did not affect the fat content in milk. As the inheritance of the Holstein breed increased, the correlation dependence of longevity traits on the Holstein heredity decreased significantly.

Key words: Ukrainian Black-and-White milk, Holstein, conditional blood, lifetime productivity

Дата надходження до редакції: 22.01.2021 р. 